\title{
The Influence of Capital Controls on Long Run Growth: Where and How Much?*
}

\author{
Areendam Chanda \\ North Carolina State University
}

September 12, 2003

\begin{abstract}
The financial crisis in East Asia generated a revival of interest in the merits of financial openness. The ensuing debate on the benefits of openness has focused more on short and medium run issues than on the long run effects. Within the empirical literature on economic growth, little or no attention has been paid to the effects of financial openness. Contrary to the orthodox position, the few results that exist suggest that capital controls have no effect on economic growth. This paper argues that this conclusion emerges from a failure to account for underlying differences across countries with similar degrees of capital controls. I show that the degree of ethnic and linguistic heterogeneity in a country plays a significant role in explaining the effects of controls on economic growth. For countries with relatively higher degrees of ethnic heterogeneity, the effects are particularly adverse whereas for countries with high degrees of homogeneity, capital controls actually have a net positive effect on economic growth. On balance, more developing countries suffered due to controls than not. Within the sample of 57 non OECD countries that did implement controls for the period 1975-95, as many as 39 saw a reduction in their growth rates. This result is robust to a number of variables commonly used in the economic growth regressions.

Keywords: Economic Growth, Capital Controls, Rent Seeking, Ethno-Linguistic Fractionalization.

JEL Classification Codes: F43, O40

${ }^{*}$ I am grateful to Oded Galor and David Weil for their advice and patience. Laura Alfaro, Phillip Garner, Tom Grennes, Louis Putterman, Enrico Spolaore and seminar participants at Brown University, University of Copenhagen, University of North Carolina at Chapel Hill, and North American Summer Meetings of the Econometric Society provided excellent comments on earlier drafts for which I am thankful. I am also grateful to Ernesto Stein for help in sharing his data. All errors are my own. Mailing address: Department of Economics, Box 8110, North Carolina State University, Raleigh, NC 27695-8110; Phone: (919)513-2867; Fax: (919)515-7873; Email: areendam_chanda@ncsu.edu
\end{abstract}




\section{Introduction}

Market discipline is the best means the world has found to ensure that capital is well used.

-Lawrence Summers (1998)

We have no evidence that it [capital account convertibility] solves any of our problems, and some reason to think that it may make them worse

-Dani Rodrik (1998)

The East Asian financial crisis and the consequent conditionalities laid down by the International Monetary Fund generated a heated debate between economists on the merits and demerits of having an open capital account. Since then, most of the debate has focused on short run issues and only a few have taken the effort to examine the long run effects. At the same time, the economic growth literature, which has grown exponentially in the past decade, too has devoted little or no time on examining in detail the empirical relationship between capital controls and economic growth. This is even more surprising given the fairly large corpus of literature that now exists on international trade and economic growth.Within the scarce literature, Dani Rodrik's finding that capital account openness generated no obvious benefit on long run growth, attracted considerable attention amongst policy makers and those involved in the openness debate. ${ }^{1}$ Based on a scatter plot of a measure of capital controls and the growth rate between 1975-89, after controlling for the initial income per capita and a few other variables, he clearly showed no perceptible correlation between the two. Not surprisingly, this evoked sharp responses from others. Eichengreen (1998) accused those, who argue that today's developing countries should resist capital account liberalization of adopting a double standard. All developed countries, he noted, opened their capital accounts- a logical culmination of the process of developing a deep financial system. While there might be valid arguments for developing countries to impose capital controls as transitional measures there are none for permanently pursuing such a policy.

In defense of Rodrik, his results are in keeping with most of the preceding literature on capital controls and economic growth. Earlier, Alesina, Grilli and Milessi Feretti (1994) found, for the sample of OECD countries, that capital controls had positive but insignificant effects on economic growth. However, their study was based on annual data and therefore reflected short run effects. Grilli and

\footnotetext{
${ }^{1}$ See Rodrik (1998)
} 
Milessi Feretti (1995) reached a similar result for the sample of developing countries based on growth over the medium run (five-year periods). The only contrary result comes from Quinn (1997), who shows that capital account liberalization (and not openness per se) has had positive effects on economic growth.

The finding that capital controls seem to have had little or no effect on economic growth warrants further investigation. At the broadest level, capital controls can be viewed as a form of government intervention. In search of the effects of capital controls, a reasonable path to follow would be to first answer the question - what is it that allows some governments to undertake successful interventions and not others? One of the strongest messages that permeate the economic growth literature is the importance of having favorable conditions and institutions in place for successful and sustained growth. Pursuing policies that artificially boost investment rates has not been sufficient to generate consistent increases in income per capita. Further, there is increasing evidence that the direction of causality between investment and growth may be from the latter to the former. Summers' quote above notwithstanding, neither does it seem to be true that the East Asian Miracle happened because of free markets. Rather government intervention was pervasive, and in this they were aided by some of these favorable conditions. ${ }^{2}$

In addressing the role of capital controls in economic growth, we pose the question: Is it that the effect (both direction and magnitude) of capital controls on economic growth is subject to the underlying conditions and institutions that seem to be so important? By entertaining such a hypothesis can one bring out the effects of capital controls from hiding? In this paper, we assess the role of political fragmentation in determining the effects of capital controls on economic growth. Using an index of ethno-linguistic heterogeneity as a proxy for fragmentation, we show that the lack of such heterogeneity played a significant role in complementing capital controls and allowed a number of countries to derive positive effects from controls on growth. On the other hand, countries with high degrees of heterogeneity experienced a decline in their growth rates because of controls. It is not surprising then, that earlier papers did not find any evidence of the effect of controls on growth. Simply entering capital controls as an independent variable in a growth regression is not the best way to search for its effects.

\footnotetext{
${ }^{2}$ See Wade (1990) for an extensive discussion. Rodrik (1995) also addresses the question of what allows governments to get interventions right. He takes the case of two countries, South Korea and Taiwan (both of which incidentally had high rates of growth but very different policies in terms of capital openness). Both these countries, he argues, grew rich not because of outward orientation but because their governments managed to engineer a significant increase in the private return to capital.
} 
The argument that political fragmentation can have a negative effect on capital controls is motivated by the political economy literature on rent seeking and common pool problems. A general reading of this literature suggests that for societies with a large number of distinct groups and insecure property rights, interventions generate opportunities for excessive appropriative behavior leading to inefficiencies. ${ }^{3}$ Being a government intervention, capital controls are also prone to this problem. If returns to investment are higher abroad, restrictions on taking capital out can create incentives for rent seeking. This may manifest itself through high black market premiums or simply resources wasted on rent seeking in order to secure shares of the limited amounts that are allowed for export. In both cases, if the economy is characterized by a large number of competing groups the effects will be worse since these groups end up diverting resources to an unproductive task while clearly some co-operative solution would have been superior. Effectively, it leads to a tragedy of commons type of problem where each group fights to maximize its own allocation but society suffers as a whole. In an economy with a high degree of ethnic heterogeneity one might expect this kind of a situation to materialize. Therefore, even if controls were imposed to generate domestic capital accumulation and higher growth rates, in divided societies rent seeking activities can choke any growth augmenting effects of controls. ${ }^{4}$

The next section of this paper presents a theoretical model which shows how controls and polarization in society can interact to affect economic growth. Section 3 discusses the data and the empirical specification. Section 4 presents the results and Section 5 concludes the paper.

\section{$2 \quad$ A model}

In this section, we develop an stylized two-period political economy model which shows how an increase in the number of distinct groups in society affects the influence of capital controls on domestic production. Controls in this story are quantitative in nature. The imposition of controls thus places limits on how much can be moved abroad. In the absence of any form of controls, each group is free to move capital in or out of the economy and there is no rent seeking. However once these controls

\footnotetext{
${ }^{3}$ For example see, Alesina and Drazen (1991), Lane and Tornell (1996, 1999), Persson, Roland and Tabellini (1997), Svennson (2000), Tornell and Velasco (1992) . For empirical applications see Easterly and Levine (1997) and Mauro (1995).

${ }^{4}$ Though not discussed here, capital controls may affect growth through a number of other channels. Dooley (1995) presents an excellent survey of the theoretical and empirical literature. Also see Edison, Klein, Ricci and Sloek (2002) and Prasad, Rogoff, Wei and Kose (2003).
} 
are imposed, groups are forced to compete with each other to ensure their share of the restricted pie. Clearly the efficient solution would be for the groups to behave in a co-operative manner and divide the pie into equal amounts. However in the absence of such a mechanism or rules to enforce it, a scramble ensues. It is assumed that the fraction extracted by each group is not costless and is a linear function of how much each group devotes to rent seeking relative to the amount spent by all groups. Thus the imposition of controls leads to a deadweight loss in society equal to the amount spent on rent seeking and has negative effects on output. As the number of groups increase in society this problem tends to get aggravated. To keep the model simple, government policy (i.e. the degree of controls) is assumed to be exogenous and we have abstracted from the question of effectiveness of controls. The model is based upon earlier work by Lane and Tornell $(1996,1999)$, Svensson (2000) and Tornell and Velasco (1992) - all of which analyse the effects of rent seeking groups on public goods and growth.

Consider a small open economy that faces a world interest rate, $r^{*}$, in the absence of any capital controls,

$$
r=r^{*}
$$

The economy's population is assumed to be $L$ and is divided into $n$ equal groups. For simplicity it is assumed that all groups are initially endowed with the same amount of wealth, $w^{i}=W / n$, where $i(=1 \ldots n)$ represents a group, $W$ represents the economy wide initial endowment. There are two factors of production in this model: private capital stock and labor. In the absence of capital controls, groups equalize returns from domestic and international investments. They first decide how much to invest domestically and how much to invest abroad. In the second stage, they consume out of their entire wage, domestic capital and foreign capital income. Group production is characterized by a standard Cobb Douglas production function:

$$
y_{t+1}^{i}=\left(l^{i}\right)^{1-\beta}\left(k_{t+1}^{i}\right)^{\beta}
$$

where $\beta \in(0,1), l^{i}=\frac{L}{n}, k_{t+1}^{i}=\frac{K_{t+1}}{n}$.

Therefore aggregate output is

$$
n y_{t+1}^{i}=Y_{t+1}=L^{1-\beta} K_{t+1}^{\beta}
$$

Groups maximize second period consumption based on first period investment decisions, ${ }^{5}$

\footnotetext{
${ }^{5}$ Since the model builds upon the assumption that competing interest groups will want to grab the maximum possible fraction of the quota, it is more convenient to view a group as an optimizing agent as well.
} 


$$
U=\ln \left(c_{t+1}^{i}\right)
$$

Capital stock in period $t+1$ is equal to endowment in the period $t$ less foreign investment, $f$,

$$
k_{t+1}^{i}=w^{i}-f
$$

$d_{t+1}^{i}$, the income from investment abroad is given by,

$$
d_{t+1}^{i}=r^{*}\left(w^{i}-s_{t}^{i}\right),
$$

where $s_{t}^{i}$, is the level of savings. Before we move onto the effects of capital controls, it is convenient to solve for the optimal values of domestic and foreign investment in the absence of any such controls.

\subsection{No Capital Controls}

In the absence of any controls, each group solves the following maximization problem,

$$
\begin{aligned}
\max \ln c_{t+1}^{i} \\
\text { subj. to } c_{t+1}^{i}=y_{t+1}^{i}+d_{t+1}^{i} \\
d_{t+1}^{i}=r^{*}\left(w^{i}-s_{t}^{i}\right) \\
y_{t+1}^{i}=\left(l^{i}\right)^{1-\beta}\left(k_{t+1}^{i}\right)^{\beta}
\end{aligned}
$$

Undertaking relevant substitutions and solving the problem for savings in the first period, we get

$$
k_{t+1}^{i}=s_{t}^{i}=\left(\frac{\beta\left(l^{i}\right)^{1-\beta}}{r^{*}}\right)^{\frac{1}{1-\beta}}
$$

This is the standard solution for a small open economy. At the aggregate level this gives us,

$$
K^{*}=K_{t+1}=L\left(\frac{\beta}{r^{*}}\right)^{\frac{1}{1-\beta}}
$$

and,

$$
Y_{t+1}=L\left(\frac{\beta}{r^{*}}\right)^{\frac{\beta}{1-\beta}}
$$

The notation, $K^{*}$, for the domestic capital stock in the absence of any controls will be useful later on. If $w^{i}>s_{t}^{i}$ then there are capital outflows (due to high $r^{*}$ ) and if $w^{i}<s_{t}^{i}$ then there are capital inflows $\left(\right.$ low $\left.r^{*}\right)$. 


\subsection{Introducing Capital Controls}

When the government imposes capital controls, it is assumed to be in the form of a limit on how much capital can flow in or out of the country. We assume that this is an aggregate sum of $\bar{F}$ each on inflows and outflows. ${ }^{6}$ Since the model does not admit the possibility of two way flows, what is of interest is the direction of flows for which this control is a binding constraint. Consider the economy where there are capital outflows, i.e. $W>K^{*}$. In the absence of any controls, the aggregate flow of investment abroad can be denoted by,

$$
F^{*}=W-L\left(\frac{\beta}{r^{*}}\right)^{\frac{1}{1-\beta}}
$$

With the imposition of controls we have, $\bar{F}<F^{*}=W-L\left(\frac{\beta}{r^{*}}\right)^{\frac{1}{1-\beta}}$. Therefore the greater the restrictions, the lower is $\bar{F}$ and the higher is $W-\bar{F}\left(>W-F^{*}\right)$. Note that in the absence of rent seeking, the effect of such a control would be to force higher domestic capital accumulation and higher GDP. Once the amount of capital that can be taken abroad is limited, each group tries to stake its claim. We assume that each group tries to extract the maximum possible given what other groups will extract. Since all groups are identical, in equilibrium, of course, all groups extract the same fraction. However, such extractive behaviour is assumed not to be costless. The fraction of $\bar{F}$ that each group can succesively extract is a linear function of the amount that it is willing to spend on such activity relative to the sum of the total amounts that groups spend. ${ }^{7}$ Therefore the "rent-seeking" structure is as follows: If group $i$ spends $x_{t}^{i}$, then it captures:

$$
\frac{x_{t}^{i}}{x_{t}^{i}+\sum_{j \neq i} x_{t}^{j}} \bar{F}
$$

To keep the analysis simple, we assume that the bribe, $x_{t}^{i}$, is a deadweight loss to society. Further, we assume that strategies are symmetric. This is a useful assumption since otherwise one needs to solve first order conditions which involve partial derivatives of the unknown strategies of the other players making the problem more complex. In equilibrium, this also means that all groups will spend equal amounts on rent seeking. For notation, this equilibrium amount will be denoted by $\alpha$ and the total amount spent on rent seeking activities will be denoted by $D=\alpha n$.

\footnotetext{
${ }^{6}$ The assumption of a quantitative restriction is purely one of convenience. Undoubtedly one could develop a similar story where the restriction lies not on the movement of capital per se but on currency leading to black market premiums, etc.

${ }^{7}$ This structure is based on Svennson (2000)
} 
Since each group takes the strategy of other groups as given, the maximization problem after relevant substitutions, now is

$$
\max _{x_{t}^{i}} \ln \left[\left(l^{i}\right)^{1-\beta}\left(w-\bar{F} \frac{x_{t}^{i}}{x_{t}^{i}+\alpha(n-1)}-x_{t}^{i}\right)^{\beta}+r^{*}\left(\bar{F} \frac{x_{t}^{i}}{x_{t}^{i}+\alpha(n-1)}\right)\right]
$$

Each group needs to choose $x_{t}^{i}$ taking the strategy of other groups as given. This yields the following first order condition

$$
\frac{\left(l^{i}\right)^{1-\beta} \beta\left(w-\bar{F} \frac{x_{t}^{i}}{x_{t}^{i}+\alpha(n-1)}-x_{t}^{i}\right)^{\beta-1}\left[-\bar{F} \frac{x_{t}^{i}+\alpha(n-1)-x_{t}^{i}}{\left(x_{t}^{i}+\alpha(n-1)\right)^{2}}-1\right]+r^{*} \bar{F} \frac{x_{t}^{i}+\alpha(n-1)-x_{t}^{i}}{\left(x_{t}^{i}+\alpha(n-1)\right)^{2}}}{\left(l^{i}\right)^{1-\beta}\left(w-\bar{F} \frac{x_{t}^{i}}{x_{t}^{i}+\alpha(n-1)}-x_{t}^{i}\right)^{\beta}+r^{*}\left(\bar{F} \frac{x_{t}^{i}}{x_{t}^{i}+\alpha(n-1)}\right)}=0
$$

Using the fact that in equilibrium $x_{t}^{i}=\alpha, D=\alpha n$ and rearranging terms we get

$$
\Rightarrow W-\bar{F}-D={\frac{\beta}{r^{*}}}^{\frac{1}{1-\beta}} L\left(1+\frac{D n}{\bar{F}(n-1)}\right)^{\frac{1}{1-\beta}}
$$

Clearly the above expression is non linear in $D$ and an explicit solution cannot be derived. However one can discuss some of the qualitative properties. Let

$$
\phi(D)=W-F-D
$$

and

$$
\psi(D)={\frac{\beta}{r^{*}}}^{\frac{1}{1-\beta}} L\left(1+\frac{D n}{\bar{F}(n-1)}\right)^{\frac{1}{1-\beta}}
$$

where

$$
\begin{aligned}
D & \in[0, W-\bar{F}] \\
\phi(D & =0)=W-\bar{F}, \phi(D=W-\bar{F})=0, \phi^{\prime}(D)=-1<0, \phi^{\prime \prime}(D)=0 ; \\
\psi(D & =0)={\frac{\beta}{r^{*}}}^{\frac{1}{1-\beta}} L, \psi(D=W-\bar{F})={\frac{\beta}{r^{*}}}^{\frac{1}{1-\beta}} L\left(1+\frac{(W-\bar{F}) n}{\bar{F}(n-1)}\right)^{\frac{1}{1-\beta}} ; \\
\psi^{\prime}(D) & >0, \psi^{\prime \prime}(D)>0
\end{aligned}
$$

Note that the lower bound of $\psi(D=0)={\frac{\beta}{r^{*}}}^{\frac{1}{1-\beta}} L$, which is nothing but, $K^{*}$, the equilibrium level of domestic capital stock in the absence of controls. Therefore, by definition, 
Figure 1: The Optimal Level of Rent Seeking

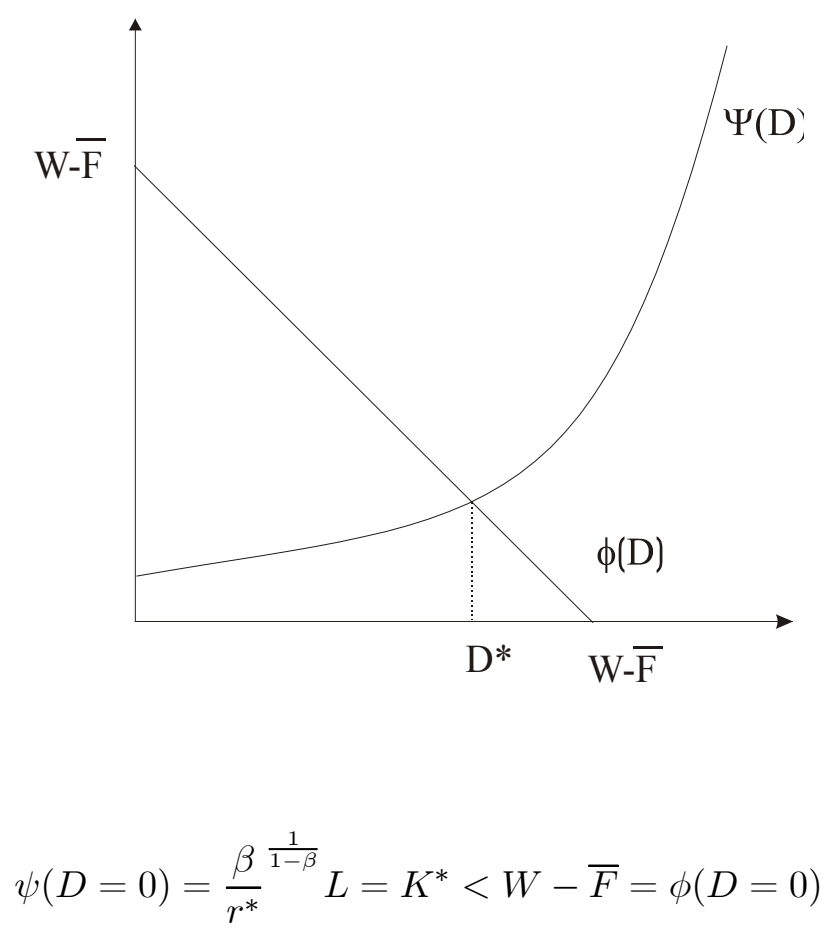

Figure 1 depicts the two functions, $\phi(D)$ and $\psi(D)$ and the unique solution for $D\left(W, \bar{F}, L, n, \beta, r^{*}\right)$. There are two comparative static exercises that are of interest: the effects of changes in $n$ and changes in $\bar{F}$. With respect to the former, one can make the following proposition,

Proposition 1 In the presence of capital controls, an increase in n, the number of competing groups, increases the total amount of resources spent on rent seeking in the economy, i.e. $\frac{\partial D}{\partial n}>0$

Proof: This follows from applying the implicit function theorem.

Using equation (6), define:

$$
\Rightarrow H\left(D ; W, \bar{F}, n, r^{*}, \beta\right)=W-\bar{F}-D-K^{*}\left(1+\frac{D n}{\bar{F}(n-1)}\right)^{\frac{1}{1-\beta}}=0
$$

Using the implicit function theorem it is easy to show that,

$$
\Rightarrow \frac{\partial D}{\partial n}=-\frac{\partial H}{\partial n} / \frac{\partial H}{\partial D}>0
$$

Note that the total amount spent on rent seeking in the economy is $\alpha n$. As $n$ increases this number tends to increase because of the second term. On the other hand $\alpha$, the amount spent on each group 
could move in either direction. As the number of competing groups increase, ceteris paribus, the endowment of each group must fall and this leaves less available to be spent on rent seeking. On the other hand, the "fair share" (ie $\bar{F} / n$ ) of each group that can be invested abroad falls which forces them to preserve, if not increase the amount spent on rent seeking to ensure that it can continue to keep it share. Finally, the alternative available for the group is to reduce the amount spent on rent seeking and increase the amount devoted to domestic capital accumulation. However since the return on this is lower than the return abroad the force of this effect is limited. Thus the overall effect on $\alpha$ is unclear but because of the opposing effects on it, its value, even if it declines, it does not do so by enough to offset the earlier proportional increase in $n$.

To figure out the effects of changes in $\bar{F}$, we can again use the implicit function theorem. This gives us,

$$
\frac{\partial D}{\partial \bar{F}}=\frac{-1+\frac{K^{*}}{\bar{F}} \frac{1}{1-\beta}\left(1+\frac{D n}{\bar{F}(n-1)}\right)^{\frac{1}{1-\beta}-1} \frac{n}{(n-1)} \frac{D}{\bar{F}}}{1+\frac{K^{*}}{\bar{F}} \frac{1}{1-\beta}\left(1+\frac{D n}{\bar{F}(n-1)}\right)^{\frac{1}{1-\beta}-1} \frac{n}{(n-1)}}
$$

The sign of this expression is ambiguous. One can try and gain some further insight by studying the movements of the curves in figure 1 . An increase in $\bar{F}$, moves $\phi(D)$ inwards while the $\psi(D)$ line becomes flatter. Depending on the relative shifts $D$ could increase or decrease. The leftward movement of $\phi(D)$ causes the amount spent on rent seeking to fall. As controls are relaxed (an increase in $\bar{F}$ ), there is less needed and available to spend on rent seeking. However since the amount of $\bar{F}$ that can be extracted is a function of the amount of resources devoted, this creates an incentive to spend more on rent seeking. The net return from investment abroad from the view of group, $i$, is $r^{*} \bar{F} \frac{\alpha}{\alpha+\sum x_{t}^{j}}-\alpha$. An increase in $\bar{F}$, therefore raises the incentive to increase $\alpha$. Of course, this is balanced by the fact that as more resources are devoted to rent seeking, the marginal product of the domestic investment increases too and thus creates a ceiling on the responsiveness of $\alpha$ to an increase in $\bar{F}$. Overall the effect of a relaxation of controls on $D$ remains unclear. One might conjecture that when the controls are high, i.e. $\bar{F}$ is low, the latter effects dominates (ie $D_{\bar{F}}^{\prime}>0$ when $\bar{F}$ is low) whereas as controls are reduced and the economy moves nearer to full capital mobility, the former effect dominates (ie $D_{\bar{F}}^{\prime}<0$ when $\bar{F}$ is high).

To analyse the effects of changes in capital controls and the number of groups on aggregate output, we can write the agregate production function as,

$$
\Rightarrow Y_{t+1}=L^{1-\beta}(W-\bar{F}-D(\cdot))^{\beta}
$$


Note that the aggregate production function in the absence of controls can be written as

$$
Y_{t+1}=L^{1-\beta}\left(W-F^{*}\right)^{\beta}
$$

Its easy to see that while capital controls tends to force capital to remain domestically, it is possible that a high enough level of rent seeking can actually lead to a reduction of capital stock and output.

One can now study the effects of capital controls and ethno-linguistic heterogeneity in the economy. From equation (11) above, one can make the following proposition,

Proposition 2 In the presence of capital controls, an increase in, $n$, the number of competing groups, decreases output in the economy, i.e. $\frac{\partial Y_{t+1}}{\partial n}<0$

Proof: The proof is straightforward. From equation (11), we can see that

$\frac{\partial Y_{t+1}}{\partial n}=-L^{1-\beta} \beta(W-F-D(\cdot))^{\beta-1} D_{n}^{\prime}(\cdot)$. Earlier we showed that $D_{n}^{\prime}(\cdot)>0$ (equation (9), so this must mean $\partial Y_{t+1} / \partial n<0$.

At the aggregate level, all that an increase in $n$ does, is divert resources away to rent seeking and reduce the amount available for domestic capital accumulation and therefore reduces domestic output. Using equation (11), it is easy to figure out the effects of changes in controls on output as well,

$$
\frac{\partial Y}{\partial \bar{F}}=L^{1-\beta} \beta(W-\bar{F}-D)^{\beta-1}\left(-1-D \frac{\prime}{F}\right)
$$

If the amount of rent seeking is insensitive to the degree of controls, ie $D \frac{\prime}{F}=0$, then empirically one should observe increasing output with increasing controls for countries where the domestic interest rate is lower than the international interest rate. However, the presence of rent seeking creates deadweight losses which eat into the domestic capital stock. The sign now depends upon the value of $D_{\bar{F}}^{\prime}$. If $D_{\bar{F}}^{\prime}<-1$, then the effects of liberalization on output would be positive and not negative. Of course, this requires that the amount spent on rent seeking increase more than the increase in controls - a condition that may not hold in reality. Earlier when discussing the sign of $D_{\bar{F}}^{\prime}$ we conjectured that it might go either way and might depend upon the degree of controls. Even if $D_{\bar{F}}^{\prime}$ is not large enough to reverse the sign of $\partial Y / \partial \bar{F}$, the fact still remains that such distortions seek to lower output. Clearly, any empirical exercise that does not take into account at least some, if not all, of these issues will not adequately capture the effect of controls on output.

To understand the effect of the interaction between the number of groups and the extent of controls, one needs to look at the second order cross derivative of output on controls and the number of groups. Differentiating the expression in equation (12) with respect to $n$ gives us, 


$$
\frac{\partial^{2} Y_{t+1}}{\partial \bar{F} \partial n}=L^{1-\beta} \beta(1-\beta)(W-\bar{F}-D)^{\beta-2}\left(-1-D_{\bar{F}}^{\prime}\right) D_{n}^{\prime}-L^{1-\beta} \beta(W-\bar{F}-D)^{\beta-1} D_{\bar{F}, n}^{\prime \prime}
$$

In order to figure out the sign of the above derivative, in addition to knowing the effects of a change in controls on rent seeking $\left(D_{\bar{F}}^{\prime}\right)$, we need to know how this effect changes as the number of groups change $\left(D_{\bar{F}, n}^{\prime \prime}\right)$. Further differentiating equation (9) with respect to $\bar{F}$, one can show that,

$$
\frac{\partial^{2} D}{\partial n \partial \bar{F}}<0
$$

If $\partial D / \partial \bar{F}>0$, i.e. liberalization increases rent seeking, then the above expression suggests that an increase in $n$ will reduce the magnitude of this increase in rent seeking. As discussed earlier, if liberalization increased the incentive to spend on rent seeking, this was because of the fact that the pie had gotten larger. Clearly an increase in $n$ forces each group to spend more for the same pie, reducing the net return and therefore reduces the marginal increase in resources devoted to rent seeking. On the other hand, if $\partial D / \partial \bar{F}<0$, i.e. an increase in capital controls led to an increase in rent seeking, this was probably because it forced people to allocate resources to domestic capital accumulation whose marginal product fell with increasing controls. Under these circumstances, each group would be better off devoting some additional resources to capturing a chunk of $\bar{F}$ which yields a higher return. If $n$ increased at the same time, this would mean that because of the direct endowment effect (reduced $W / n$ ), each group would be forced to devote less to domestic capital accumulation which already gives a lower return making it marginally more attractive to devote resources to rent seeking.

Finally to analyze the effect of capital controls, it is more convenient to define $\bar{X}=K^{*}-\bar{F}$ as the level of capital controls. Since $d \bar{X} / d \bar{F}=-1$, it is easy to verify that $D_{\bar{X}, n}^{\prime \prime}>0$ and equation (12) can be rewritten as

$$
\frac{\partial Y_{t+1}}{\partial \bar{X}}=L^{1-\beta} \beta\left(W-K^{*}+\bar{X}-D\right)^{\beta-1}\left(1-D_{\bar{X}}^{\prime}\right)
$$

where $D_{\bar{X}}^{\prime}=-D_{\bar{F}}^{\prime}$. This notation is convenient to analyze the effects of the interaction of controls and the number of groups on aggregate output. This also implies that the second order cross derivative (13) can be rewritten as,

$$
\begin{aligned}
\frac{\partial^{2} Y_{t+1}}{\partial \bar{X}_{t} \partial n}= & L^{1-\beta} \beta(1-\beta)\left(W-K^{*}+\bar{X}_{t}-D\right)^{\beta-2}\left(1-D_{\bar{X}_{t}}^{\prime}\right) D_{n}^{\prime} \\
& -L^{1-\beta} \beta\left(W-K^{*}+\bar{X}_{t}-D\right)^{\beta-1} D_{\bar{X}_{t}, n}^{\prime \prime}
\end{aligned}
$$


Proposition 3 An increase in the number of groups, $n$, worsens the effect of capital controls on output if $D_{\bar{X}_{t}}^{\prime}>1$

Proof: This follows from equation (16). Note that if $D_{\bar{X}_{t}}^{\prime}>1, \partial^{2} Y_{t+1} / \partial \bar{X}_{t} \partial n<0$. Further, from equation (15), we can see that if $D_{\bar{X}_{t}}^{\prime}>1$ then $\partial Y_{t+1} / \partial \bar{X}_{t}<0$.

Therefore, if an increase in capital controls reduces output, then an increase in the number of competing groups will worsen the negative effect on output. As long as $D_{\bar{X}_{t}}^{\prime}>1$, an increase in controls reduces output because of what is lost in rent seeking activities. An increase in the number of groups tends to increase the amount of rent seeking that takes place, $D_{n}^{\prime}>0$ (from proposition (2)) thus making the situation worse. Clearly $D_{\bar{X}_{t}}^{\prime}>1$ is a sufficient condition and not a necessary one. Even if it is not satisfied it is still possible that while an increase in controls may lead to higher output, an increase in rent seeking due to an increase in $n$ lowers the rise in output.

\section{Model Specification and Description of the Data}

The empirical exercise seeks to answer two questions: a) Do capital controls have any effect on economic growth? b) Are these effects influenced by the degree of ethnic homogeneity in a country? The model outlined above is a static one (though, with some exogenous technological change or adjustment costs one could obtain dynamic versions) and in keeping with that one needs an empirical specification that tries to capture transitional effects rather than steady state effects. Based on the existing practice in the growth literature, the first question is then addressed by estimating equations of the following variety

$$
g_{i}=a+b_{y} Y_{i}+B_{x}^{\prime} X_{i}+b_{c} C_{i}+e_{i}
$$

where $i$ indexes countries, $g_{i}$ is the average growth rate of per capita income (GDP per capita) for the period being investigated, $y_{i}$ is the logarithm of the initial GDP per capita, $X_{i}$ is vector of other variables that are believed to affect the growth rate in transition to the steady state and $C_{i}$ is the capital control index. The specification here attempts at being as close as possible to Rodrik (1998) and therefore includes in $X_{i}$, a schooling variable, an indicator of institutional quality, and dummy variables for East Asia, Latin America and Sub-Saharan Africa. The list is later extended to include other variables to test for robustness.

To address the second question, based on the model above, another variable is added which is the interaction between capital controls and ethnic homogeneity: $C_{i} \times E_{i}$ where $E_{i}$ is the measure of 
ethnic homogeneity. To ensure that this interaction term does not proxy for ethnic homogeneity per se, $E_{i}$ is also added to the list of independent variables. Thus empirical specification is now,

$$
g_{i}=a+b_{y} Y_{i}+B_{x}^{\prime} X_{i}+b_{c} C_{i}+b_{c e}\left(C_{i} \times E_{i}\right)+b_{e} E_{i}+e_{i}
$$

The measure of institutional quality that is used here is from the International Country Risk Guide published annually by Political Risk Services. The variable was introduced into the literature by Knack and Keefer (1995) and has been found to be a better indicator of the impact of property rights on economic growth than measures such as revolutions, coups, assassinations, etc. Further the model in section 2 does not account for the fact that changes in the level of enforceability of property rights can lead to changes in the optimal appropriation amount. So, at least such differences should be controlled for in the empirical specification. To measure the lack of political fragmentation, we use the ethno-linguistic homogeneity (ELH) measure used here is equal to one minus the ethnolinguistic fractionalization index, AVELF (ELH=1-AVELF), variable used in Easterly and Levine (1997). Clearly this is not the best indicator for political fragmentation but is probably the most widely available and has already been used in a number of empirical studies. Later, while doing robustness checks we use some alternative variables but these are restricted to smaller samples. Data for the growth rate in GDP and Real GDP per capita was taken from the World Bank's Global Development Network Growth Database. The education variable used here is the average years of secondary schooling for the period $1975-95 .^{8}$

Those familiar with the empirical literature are only too aware of the limitations of the data on capital controls. Unlike the variety of indices that are readily available or have been created to measure openness in international trade, there is only one traditionally used variable for financial openness. ${ }^{9}$ The IMF's annual publication, Exchange Arrangements and Exchange Restrictions, has, since 1967, included a table that lists whether each country had in place various restrictions on exchange rates and payments on international transactions. The table also lists whether countries had restrictions on payments for capital transactions. The limitation is that this entry is completely binary. Countries are either deemed to have controls in place or they are not. ${ }^{10}$ The obvious drawback of such data is that

\footnotetext{
${ }^{8}$ Originally introduced in Barro and Lee (1993), the data here is the updated version downloaded from http://www.cid.harvard.edu.

${ }^{9}$ Though the adequacy of these trade openness indices has recently been put to doubt by Rodrik and Rodriguez (1999).

${ }^{10}$ Other measures of capital mobility based on offshore interest rate differentials, black market premium and deviations from covered interest rate parity exist. However these measures are more endogenous rather than an explicit indication of policy.
} 
there is no indication of the degree of capital controls making it difficult to extract much information. Further there is no way one can distinguish between various types of capital controls. For example, one cannot distinguish between controls which some may consider desirable, such as those on short-term flows and those which may not be so, such as on foreign direct investment. Finally, there is no way to distinguish between restrictions on inflows and outflows. ${ }^{11}$

The index of capital controls that we construct is a share based on the crude measure that is available. A dummy variable is created with a country that had capital controls in place in a given year taking the value 1 , and if it had no capital controls in place, taking the value 0 . Then for the period of study (1975-95), the capital control index is calculated by dividing the number of years it had controls in place by the length of that period. This is, in principle, the same measure constructed by Rodrik (1999) and Klein and Olivei (1999). In order to maximize the number of countries in the sample, any country that has a dummy variable for more than 16 years (80\%) was included. Clearly this is an imperfect measure of capital controls but seemingly one of the few options that are available. In the rest of the paper this index is referred to as CAPCON1.

In order to corroborate the results, we also used a similar variable published by the Fraser Institute in its Economic Freedom of the World: 2000 Annual Report. ${ }^{12}$ The aim of the report "is to construct an indicator of economic freedom of nations around the world... The goal is to develop an objective measure of economic freedom rather than an index based on subjective assessments and judgement calls." The index is composed of seven sub-indices reflecting institutional arrangements and policies in major areas. The fourth such sub-index is the freedom to use alternative currencies. This index itself receives a weight of $14.6 \%$ in the final index based on principal component analysis. The ratings for freedom to use alternative currencies is further built on two other indices labelled " $4 \mathrm{~A}$ " and " $4 \mathrm{~B}$ " each having a $50 \%$ weight. The index under label $4 \mathrm{~A}$ measures the freedom of citizens to own foreign currency bank accounts domestically and abroad. Index 4B measures the "Difference between the Official Exchange Rate and the Black Market Rate". Since the latter is similar to the black market premium used commonly in the growth literature, we left it out of the analysis though it is used for some robustness tests later. The former is based on information gathered from Currency Data and Intelligence Inc., World Currency Yearbooks (various issues) and the IMF Exchange Arrangements and Exchange Restrictions (various issues). When foreign currency bank accounts were permissible

\footnotetext{
${ }^{11}$ More recent issues of the same publication, beginning from 1996, carry a more disaggregated analysis of restrictions on capital transactions. While empirical analysis with the newer data set has begun to appear (see Johnston and Tamirisia (1998)), the span is much too short for any long run study.

${ }^{12}$ See Gwartney, Lawson and Samida (2000).
} 
without restrictions both domestically and abroad, the rating was 10 . When these accounts were restricted, the rating was zero. If foreign currency bank accounts were permissible domestically but not allowed abroad (or vice versa), the rating is 5 . The data for this index is available quinquennially beginning from 1970. However there is a jump in the sample size from 1975 onwards. Though the index is not a considerable improvement over the share variable, nevertheless we used it to reconfirm the results. In the rest of the paper this index is labelled CAPCON2.

It is instructive to note how both CAPCON1 and CAPCON2 have behaved over the past decades. Out of a total of 111 countries, only 17 had no capital controls at all during 1976-80 as measured by CAPCON1. There were as many as 87 countries with a CAPCON1 value of 1 during the same period. Though the sample of countries for which IMF has data increases to 157 in the period 1991-95, the description in terms of the values CAPCON1 takes remains pretty much the same. In percentage terms the number of countries with a value of 1 drops from $78 \%$ to $71 \%$. If the phenomenon of "globalization" does not seem to be supported by CAPCON1, it clearly does with CAPCON2. In 1975, almost half of the sample have a value equal to 1 . By the time one reaches 1995, as much as two-thirds of the sample do not have a value of one and as many as $40 \%$ have a value of zero. Table 1 presents the correlations between the two variables. Both variables have a reasonably high correlation over time with the correlations being lower the further the variables are placed from each other in terms of the period of measurement. For the entire period, 1975-95, the correlation between the two indices is fairly high at 0.73 .

\section{Growth Regressions}

The correlation between the growth rate for the period 1975-95 and the capital controls indices are -0.30 for CAPCON1 (based on the maximum sample of 82 countries used in this study) and -0.25 for CAPCON2 (based on a maximum sample of 82 countries). Though not particularly high they are indicative of some degree of a negative association. A simple regression of the growth rate on CAPCON1 after controlling for the initial income per capita produces a coefficient of -1.11- statistically significant at the $10 \%$ level. CAPCON2 also has a negative sign but the coefficient is not significant. In Table 2, results similar to the regression carried out by Rodrik are presented. Columns (3) and (4) reproduce the results using the same specification for all countries. The independent variables include the log of initial GDP per capita, average years of secondary schooling for the period 197595 (SYR7595), the Knack and Keefer (1995) institutional quality measure (INSTTN) and regional 
dummies for East Asia, Latin America and Sub Saharan Africa. Columns (5) and (6) repeat the results with only non-OECD countries included in the sample. If there is any influence of capital controls on economic growth, it is not apparent here. In fact in the regressions that include all countries, it is the only variable that is not of any importance. ${ }^{13}$

As argued in section 2, the effects of capital controls on economic growth is a negative function of the number of appropriative groups that exist in society. The index of ethno-linguistic fractionalization popularized by Easterly and Levine (1997) is one rough measure of such division in society. Of course, it is not a sufficient measure of such groupism. It is possible that countries may have high degrees of ethnic plurality and yet be more unified than countries which are ethnically homogenous. However given that this is the only measure that has been shown empirically to have a significant negative effect on economic growth, it is the one we adopt. Columns (1) and (2) in Table 3 add the ethnic homogeneity indicator to the list of independent variables. The strong positive effects of homogeneity found be Easterly and Levine (1997) are clearly reproduced here. Both capital control variables still do not show any significant effect. In keeping with the results of the theoretical section, one needs to add an interaction term to the specification. Columns (3) and (4) add the terms ELH $\times$ CAPCON1 and $\mathrm{ELH} \times \mathrm{CAPCON} 2$ to the specification in Column (1) and Column (2). The change in the direct effects of capital controls are nothing if not dramatic. CAPCON1 now is significant at the $5 \%$ level and CAPCON2 does even better being significant at 1\%. Since a lot of the variation in the data on controls can be attributed to OECD countries, Columns (4) and (5) repeat the results with those countries dropped. Again both indicators retain their strong significance. Finally we dropped Hong Kong and Taiwan from the sample as both of them were very high growth countries that have values of zero for CAPCON1 and CAPCON2. Results (5) and (6) clearly suggest that two countries are not driving the results. In addition to the CAPCON variables, the model in the earlier sections suggests that the interaction term should be significant. Indeed, in each of the results in Table 3 where it has been included, it is strongly significant.

A cursory look at the coefficients of CAPCON1 (and CAPCON2) and the respective interaction terms suggest that within countries that imposed complete capital controls, those with complete ethnic homogeneity $(\mathrm{ELH}=1)$ were in a position to offset the negative effects of capital controls. For example, a country with complete homogeneity could move from complete openness to being completely closed and experience an absolute increase of $0.78 \%$ in its annual growth rate. Alternatively, if a country that was completely heterogenous $(\mathrm{ELH}=0)$

\footnotetext{
${ }^{13}$ The OECD countries for this paper are the "older" set and do not include newer members such as Mexico and Korea.
} 
moved from being open to closed, it would experience a decrease of $3.77 \%$ in its annual growth rate. No country of course has complete heterogeneity. Looking at specific countries, as many as 34 countries managed to more than offset the pure negative effects of capital controls and had a net positive effect because of relatively high degrees of ethnic homogeneity. Of this 18 were non OECD countries. Of course this list does not include countries that were completely open (The sum of their coefficients for CAPCON1 and CAPCON1 $\times$ ELH is trivially zero). On the other hand as many as 39 developing countries suffered due to capital controls.

Using the estimated coefficients on the sample, developing countries that managed to derive a positive effect include Bangladesh, Korea, Dominican Republic, Jamaica and Egypt. Not one of the sub-saharan African countries make it to the list. In fact, no sub-Saharan African country derived a positive effect from capital controls. Easterly and Levine (1997) noted that the ethno-linguistic heterogeneity particularly adverse effects in the same region. These results reinforce their findings. Looking at negative effects of capital controls, a total of 40 countries ended up with an overall negative effect on economic growth. Relatively similar results emerge when using CAPCON2. With CAPCON2, 31 countries managed to offset the negative effect while 34 countries experienced a net positive effect.

Figure 2 shows scatterplots of the component of growth predicted by capital controls and the interaction of capital controls with ethnic homogeneity. On the basis of Column (3) in Table 3, the horizontal axis in figure 2 is therefore $-3.77 \times$ CAPCON1 $+4.45(\mathrm{CAPCON} 1 \times$ ELH) . The vertical axis is the actual growth rate during the same period. The plot suggests a positive relationship with some interesting features. First, almost all OECD countries are cluttered at or around the predicted value of 0 in both figure. This is to be expected since most of them had approximately a zero value of capital controls through the entire period. Looking at the figure one clearly sees the so called "gang of four" East Asian nations (Hong Kong, Korea, Singapore and Taiwan) are grouped at the top right hand corner with Korea being placed at the extreme. The problem of the gang of four in growth regressions has been discussed earlier in Easterly (1995). ${ }^{14}$ To ensure the results are robust, we re-estimated the model but dropped these four nations from the sample. The results are reproduced in Columns 1 and 2 of Table 4. Again Capital Controls has a significant negative effect while the interaction term has a significant positive effect on growth.

Since Levine and Renelt (1992), there has been a growing awareness of the problem of robustness of growth regressions. Table 3 already included a fair number of important variables against which many so called determinants of growth fail. In particular continental dummies tend to reduce the

\footnotetext{
${ }^{14} \mathrm{~A}$ similar pattern is observed when the scatterplot exercise is repeated for CAPCON2.
} 
Figure 2: Predicted Growth Rate (Based on CAPCON1)

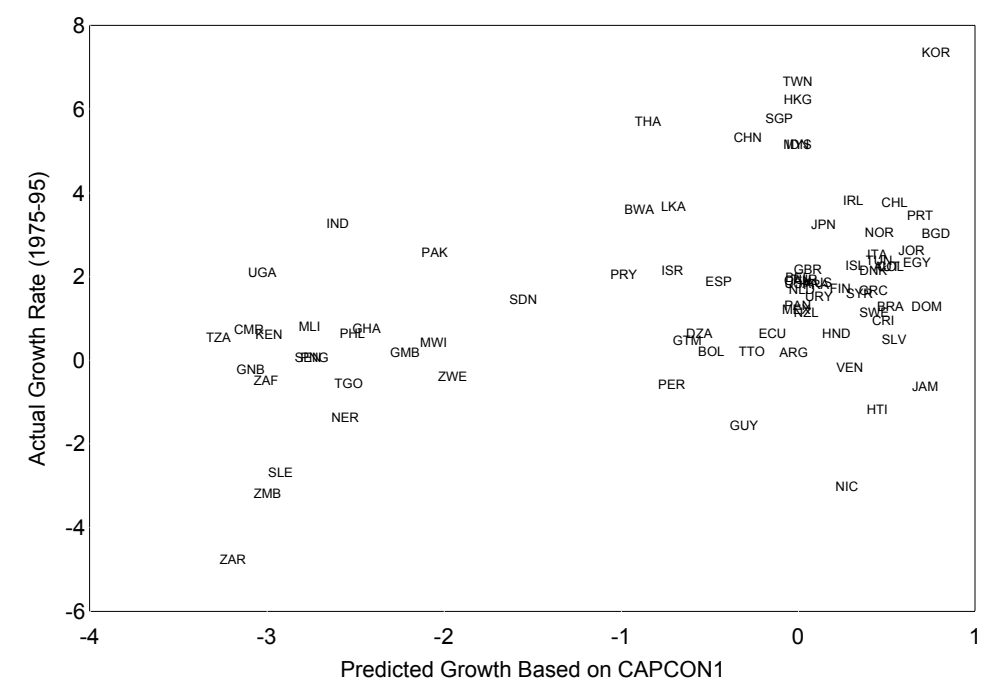

significance of a number of determinants of growth considerably. However the capital controls story is not affected by these variables. Table 4 present some further robustness results. For all these regressions the gang of four was dropped to rule out their role in driving the results. In columns (3) and (4) we add a whole bunch of control variables- the log of the investment rate, the inflation rate, initial life expectancy, a measure of trade, and two interaction terms: between homogeneity and a) initial log gdp per capita and b) institutional quality. The first variable in the list is the log of the investment ratio. This variable is one of the few that is consistently significant in the multitude of growth regressions that now exist in the literature. The inflation rate is included simply as an indicator of the macroeconomic siuation in the country, while the life expectancy variable is included as an indicator of non educational human capital. Further, the latter was one of the few variables found consistently robust in the million regressions run in Sala-i-Martin (1997). We also include a a measure of openness in international trade- the volume of exports plus imports as a share of output (TRADEVOL) for the 1975-95 . CAPCON1 and the volume of trade index have a negative correlation of -0.28 for the sample of countries for which data is available. Further the latter index has a positive correlation of similar magnitude with the growth rate.

As argued earlier, the importance of ethno-linguistic homogeneity in growth might itself be a function of the level of development. At higher levels of development homogeneity might be less 
important. Further capital controls itself might be a negatively correlated with the growth of income per capita. Under such circumstances it is possible that the interaction between capital controls and homogeneity is really a measure of the interaction between income per capita and homogeneity. Another problem is the correlation between capital controls and institutional quality. Most of the countries that seem to have suffered due to controls also rank low in terms of institutional quality. This suggests that capital controls might be acting as a proxy for bad institutional quality. In fact, Easterly (2000) suggests that ethnic fragmentation might be less of a problem in economies with better institutions. To address these issues, we also added interaction terms between homogeneity and a) income per capita and b) institutional quality. Despite adding all these control variables, both the interaction term and the capital controls variable have significant effects. Columns $5 \& 6$ drop all OECD countries in addition to the East Asian tigers. Though the sample size falls drastically, the results are still very strong. ${ }^{15}$

All these results suggest convincingly that indeed having an ethnically heterogenous society may have actually led capital controls to have adverse effects on economic growth. There are issues of endogeneity that we have not considered here. However, that is less likely to be a problem. One reason the whole exercise was undertaken was because of the observation that growth and capital controls do not have a direct significant correlation. Therefore the notion that capital controls were less in countries with higher growth rates is not a relationship that should pose a problem for the inferences arrived at here. Ethno-linguistic division is also one of the few variables that can legitimately be considered exogenous in growth regressions. ${ }^{16}$

Table 5 lists some additional robustness results. Capital controls themselves might be negatively correlated with ethnic homogeneity. In that case, it is quite possible the interaction term in all of the earlier regressions is really picking up the non linear effect of homogeneity. Columns (1) and (2) repeat the regressions for CAPCON1 and CAPCON2 respectively with the square of the ethnic homogeneity term added. The estimates clearly rule out this possibility. Instead of CAPCON1 and CAPCON2, in Column (3) we used the average of black market premium (BMP) of the exchange rate as an indicator

\footnotetext{
${ }^{15} \mathrm{~A}$ number of additional robustness exercises were conducted. These included estimating a SUR model with two periods (75-85, 85-95) and repeating everything shown in the tables, extending the time period further back to 1967 for CAPCON1 and dropping all OECD countries for each of the results displayed. These are all available upon request.

${ }^{16}$ However some additional estimation exercises were performed using lagged values of restrictions on current account and capital account as instruments. Klein and Olivei (1999) also suggest the use of a regrouping of continental dummies as instruments for controls. The results with all these instruments continued to be robust.
} 
for controls. ${ }^{17}$ Of course, BMP is more endogenous and might reflect more than just capital controlsit may reflect bad macroeconomic conditions or even trade distortions rather than capital controls. In column (3) we substitute BMP as the capital control variable. The average of the inflation rate is also added to control for other macroeconomic factors. The results are similar in spirit to the ones found earlier though the interaction term is significant only at the $10 \%$ level. In column (4) we added the trade share measure used earlier and now the interaction term, while still positive, is not signifcant at the $10 \%$ level- which is not surprising.

In addition to ethnic homogeneity, high levels of human capital stock relative to income can also be expected to help government interventions, including capital controls, work better. High levels of human capital imply the availability of a skilled labor force that allows the formation of a competent bureaucracy. In addition to looking at the effects of ethnic heterogeneity, we test for the roles of human capital in influencing the effect of capital controls on growth. As seen in columns (5) and (6), compared to the effects of ethnic homogeneity, the benefits of having high levels of human capital seem to be less significant. Of course, these findings could be a consequence of the well known problem that formal measures of human capital do not adequately reflect the true stock of human capital in an economy.

Finally, ethno-linguistic diversity is just one indicator of political fragmentation though undoubtedly a widely available and clearly exogenous one. To check for robustness, we used two alternative measures of political fragmentation examined earlier by Stein, Talvi and Grisanti (1999). These measures are the "number of effective parties" (EFEC) and the logarithm of "district magnitude" (LDM). The former is is a weighted average of the number of parties in the legislature where each party is weighed by its share of votes in the legislature. The latter measures the average number of representatives elected per district. Stein et. al. (1999) showed that for Latin American countries, higher values of either variable are associated with larger governments, larger deficits, and a more procyclical response to the business cycle. ${ }^{18}$ The variables are however available only for OECD and Latin American countries and that too for the period 1991-95. Moreover, the countries that exhibit the highest fragmentation tend to be OECD countries. This clearly creates a problem since the motivation for this paper rests implicitly, to some degree, on the inability of countries to have good enough institutional arrangements to prevent excessive rent seeking. To partially address this problem both measures of political fragmentation were adjusted for institutional quality using the ICRG measure- a strategy

\footnotetext{
${ }^{17}$ As has become standard practice, the measure here is $\log (1+\mathrm{BMP})$

${ }^{18}$ For a theoretical rationale see Talvi and Vegh (2000).
} 
similar to that in Lane and Tornell (1996). ${ }^{19}$ Despite all these limitations, it's worthwhile to check if these variables come close to replicating the results derived using ethno-linguistic homogeneity. Table 6 lists the regression results. Since the sample size falls to 35 countries, we removed the schooling variable (which was not significant in earlier runs). While the results are not as strong as those with ethno-linguistic fractionalization, they are still significant and reinforce the arguments being put forth in this research. In general, capital controls can have a positive effect on growth. However, the greater the political fragmentation, the lower the benefits from capital controls. ${ }^{20}$

\section{Conclusion}

Existing empirical research suggests no significant relationship between capital account liberalization and economic growth. This has led to questioning the usefulness of opening the capital account. This paper shows that on deeper examination, capital controls do have an important effect on economic growth. As with any other government intervention the success or failure of capital controls depends crucially on some underlying factors. One such important condition turns out to be the level of ethnic and linguistic heterogeneity in society to that extent that it might proxy for a measure of the the number of interest groups in society. Depending on a country's degree of heterogeneity, capital controls can have negative or positive effects. For countries with high degrees of heterogeneity, capital controls leads to greater inefficiencies and lower economic growth. It is not therefore surprising that many economists and policy makers oppose controls because they tend to promote rent-seeking. At the same time, for countries which did not have such heterogeneity, it was shown that capital controls worked to enhance economic growth. On balance, it turns out that within the sample of non OECD countries which were used for estimation and which had some capital controls in place, as many as 39 had a net negative effect of capital controls on growth and only 18 had a net positive effect. If one uses the coefficients estimated in Table 3 and applies them to countries that could not be used for estimation but for which data on capital controls and ethno-linguistic homogeneity are available, the division becomes even more unbalanced. Another 32 non OECD countries experienced a net negative

\footnotetext{
${ }^{19}$ The maximum value of the ICRG index is 10 . Therefore each of the two variables was multiplied by (10-ICRG). Lane and Tornell (1996) adopt a similar strategy though they instead multiply their variable of interest with a dummy variable for ICRG. In their work, countries with an above median value of ICRG are assigned a value of 1 and the rest, 0.

${ }^{20}$ Note that in this table the interaction term is capital controls interacted with political fragmentation whereas in earlier tables we interacted capital controls with ethnic homogeneity. This causes the reversal of signs of coefficients of both the interaction variable and the capital controls variable when compared to earlier tables.
} 
effect from capital controls taking the total number of countries with a net negative effect to 71 (out of 99$).^{21}$

These findings imply that one needs to take a more nuanced view of the way policies tend to work instead of expecting to find a direct negative or positive effect. The inferences are all the more interesting given the fact that the data that was used provided fairly limited information.

\section{References}

[1] Alesina, Alberto and Allen Drazen, 1991, Why Are Stabilizations Delayed, American Economic Review, LXXXI: 1170-1188.

[2] Alesina, Alberto, Vittorio Grilli and Gian M. Milesi-Ferretti, 1994, The Political Economy of Capital Controls, in Leonardo Leiderman and Assaf Razin, ed., Capital Mobility: The Impact on Consumption, Investment and Growth,Cambridge: Cambridge University Press, pp 289-321.

[3] Barro, Robert and Lee, Jong-Wha, 1993, International Comparisons of Educational Attainment, Journal of Monetary Economics, December, 32(3), pp363-394.

[4] Benhabib, Jess and Mark M. Speigel, 1994, The Role of Human Capital in Economic Development: Evidence from Aggregate Cross Country Data, Journal of Monetary Economics, October, 34(2), 143-73.

[5] Dooley, Michael P., 1995, Survey of Academic Literature on Controls over International Capital Transactions, NBER Working Paper No. 5352, Cambridge, November.

[6] Easterly, William, 2000, Can Institutions Resolve Ethnic Conflict?, mimeo, World Bank, Washington D.C.

[7] Easterly, William, 1995, Explaining Miracles: Growth Regressions Meet the Gang of Four, in Takatoshi Ito and Anne O. Krueger, eds. Growth theories in light of the East Asian experience. National Bureau of Economic Research-East Asia Seminar on Economics series, vol. 4. Chicago and London: University of Chicago Press, pages 267-90

[8] Easterly, William and Ross Levine, 1997, Africa's Growth Tragedy: Policies and Ethnic Divisions, Quarterly Journal of Economics, November, 1203-1250.

\footnotetext{
${ }^{21}$ These 32 countries were not included in the estimation because either data on growth rates, initial GDP per capita, education or institutional quality were not available.
} 
[9] Edison, Hali J, Michael W Klein, Luca Ricci, Torsten Sloek, 2002, Capital Account Liberalization and Economic Performance: Survey and Synthesis, NBER Working Paper, Cambridge, No. 9100 (August).

[10] Edwards, Sebastian, 1999, How Effective Are Capital Controls, NBER Working Paper, Cambridge, No.7413 (November).

[11] Eichengreen, Barry, 1998, Capital Controls: Capital Idea or Capital Folly, Manuscript, November.

[12] Gwartney, Jim and Robert Lawson with Dexter Samida, 2000, Economic Freedom of the World: 2000 Annual Report, Vancouver: The Fraser Institute. Data retrieved from http://www.freetheworld.com

[13] Grilli, Vittorio and Gian M. Milesi-Ferretti, 1995, Economic Effects and Structural Determinants of Capital Controls, IMF Staff Papers, 42(3), 517-551.

[14] Johnston, Barry and Chris Ryan, 1994, The Impact of Controls on Capital Movements on the Private Capital Accounts of Countries' Balance of Payments: Empirical Estimates and Policy Implications, IMF Working Paper, Washington D.C., No. 94/78.

[15] Johnston, Barry and Natalia T. Tamirisia, 1998, Why do Countries Use Capital Controls, IMF Working Paper, Washington D.C., No. 98/181.

[16] Klein, Michael and Giovanni Olivei, 1999, Capital Account Liberalization, Financial Depth and Economic Growth, NBER Working Paper, Cambridge, No.7384 (October).

[17] Knack, Stephen and Phillip Keefer, 1995, Institutions and Economic Performance: Cross Country Tests Using Alternative Institutional Measures, Economics and Politics, 7(3), 207-227.

[18] Lane, Philip and Aaron Tornell, 1996, Power Growth and the Voracity Effect, Journal of Economics Growth, 1(2): 213-41.

[19] Lane, Philip and Aaron Tornell, 1999, The Voracity Effect, American Economic Review, March, $89,22-46$.

[20] Levine, Ross and David Renelt, 1992, A Sensitivity Analysis of Cross Country Growth Regressions, American Economic Review, 82(4), 942-963.

[21] Mauro, Paolo, 1995, Corruption and Growth, Quarterly Journal of Economics, CX: 681-712. 
[22] Persson, Torsten, Gerard Roland, and Guido Tabellini, 1997, Separation of Powers and Accountability, Quarterly Journal of Economics, CXII: 1163-1202.

[23] Prasad, Eswar, Kenneth Rogoff, Shang-Jin Wei and M Ahyan Kose, 2003, Effects of Financial Globalization on Developing Countries: Some Empirical Evidence, IMF Survey Paper, March.

[24] Quinn, Dennis, 1997, The Correlates of Changes in International Financial Regulation, American Political Science Review, 91(3), 531-551

[25] Rodriguez, Francisco and Dani Rodrik, 1999, Trade Policy and Economic Growth: A Skeptic's Guide to the Cross-National Evidence, Manuscript (April).

[26] Rodrik, Dani, 1998, Who Needs Capital Account Convertibility?, In Stanley Fischer and others, Should The IMF Pursue Capital-Account Convertibility? Essays in International Finance No. 207, Princeton University, May.

[27] Rodrik, Dani, 1995, Getting Interventions Right: How South Korea and Taiwan Grew Rich, Economic Policy, Vol.20.

[28] Stein, Ernesto, Ernesto Talvi and Alejandro Grisanti, 1999, Institutional Arrangements and Fiscal Performance: The Latin American Experience in James M Poterba and Jurgen von Hagen ed Fiscal Institutions and Fiscal Performance, NBER, Cambridge, pp 103-133.

[29] Summers, Lawrence, 1998, Building an International Financial Structure for the 21st century, Remarks to the Cato Institute, Washington D.C.

[30] Svennson, Jacob, 2000, Foreign Aid and Rent Seeking, Journal of International Economics, 51, 437-461.

[31] Talvi, Ernesto and Carlos Vegh, 2000, Tax Base Variability and Procyclical Fiscal Policy, NBER Working Papers 7499, National Bureau of Economic Research, Cambridge.

[32] Tornell, Aaron and Andres Velasco, 1992, The Tragedy of the Commons and Economic Growth: Why Does Capital Flow from Poor Countries to Rich Countries?, Journal of Political Economy, 100(6): 1208-1231.

[33] Wade, Robert, 1990, Governing the Market: Economic Theory and the Role of the Government in East Asian Industrialization, Princeton: Princeton University Press. 
Table 1

Correlations between Capital Control Indices ${ }^{22}$

\begin{tabular}{|c|c|c|c|c|c|c|c|c|c|c|c|}
\hline & C17680 & C18185 & C18690 & C19195 & C275 & C280 & C285 & C290 & C295 & C17595 & C27595 \\
\hline \multicolumn{12}{|l|}{ C17680 } \\
\hline & & & & & & & & & & & \\
\hline \multirow[t]{2}{*}{ C18185 } & 0.7231 & 1 & & & & & & & & & \\
\hline & & & & & & & & & & & \\
\hline \multirow[t]{2}{*}{ C18690 } & 0.6184 & 0.8354 & 1 & & & & & & & & \\
\hline & & & & & & & & & & & \\
\hline \multirow[t]{2}{*}{ C19195 } & 0.5823 & 0.6776 & 0.8422 & 1 & & & & & & & \\
\hline & & & & & & & & & & & \\
\hline \multirow[t]{2}{*}{ C275 } & 0.718 & 0.5789 & 0.5052 & 0.5032 & 1 & & & & & & \\
\hline & & & & & & & & & & & \\
\hline \multirow[t]{2}{*}{ C280 } & 0.708 & 0.5259 & 0.4642 & 0.4733 & 0.9282 & 1 & & & & & \\
\hline & & & & & & & & & & & \\
\hline \multirow[t]{2}{*}{$\mathbf{C 2 8 5}$} & 0.6102 & 0.6178 & 0.5077 & 0.5057 & 0.7617 & 0.8457 & 1 & & & & \\
\hline & & & & & & & & & & & \\
\hline \multirow[t]{2}{*}{$\overline{\mathrm{C} 290}$} & 0.5317 & 0.5873 & 0.5709 & 0.6597 & 0.6155 & 0.6496 & 0.7233 & 1 & & & \\
\hline & & & & & & & & & & & \\
\hline \multirow[t]{2}{*}{$\overline{\mathrm{C} 295}$} & 0.3664 & 0.4268 & 0.4441 & 0.5852 & 0.4282 & 0.4107 & 0.4605 & 0.7276 & 1 & & \\
\hline & & & & & & & & & & & \\
\hline \multirow[t]{2}{*}{ C17595 } & 0.8212 & 0.9101 & 0.9315 & 0.8809 & 0.6593 & 0.6198 & 0.6411 & 0.6696 & 0.5249 & 1 & \\
\hline & & & & & & & & & & & \\
\hline \multirow[t]{2}{*}{$\overline{\mathrm{C} 27595}$} & 0.6965 & 0.6478 & 0.5909 & 0.6479 & 0.874 & 0.8985 & 0.89 & 0.8782 & 0.7136 & 0.7355 & 1 \\
\hline & & & & & & & & & & & \\
\hline
\end{tabular}

${ }^{22} \mathrm{C} 1$ refers to CAPCON1 and $\mathrm{C} 2$ refers to CAPCON2. The number below each correlation refers to the no. of observations 
Table 2

Capital Controls and Long Run Growth ${ }^{23}$

(Dependent Variable: Growth Rate per Capita 1976-95)

\begin{tabular}{|c|c|c|c|c|c|c|}
\hline & 1 & 2 & 3 & 4 & 5 & 6 \\
\hline & $\begin{array}{c}\text { All } \\
\text { Countries }\end{array}$ & $\begin{array}{c}\text { All } \\
\text { Countries }\end{array}$ & $\begin{array}{c}\text { All } \\
\text { Countries }\end{array}$ & $\begin{array}{c}\text { All } \\
\text { Countries }\end{array}$ & $\begin{array}{c}\text { Non } \\
\text { OECD }\end{array}$ & $\begin{array}{c}\text { Non } \\
\text { OECD }\end{array}$ \\
\hline $\begin{array}{c}\text { Log of } G D P \\
\text { p.c. } 1975\end{array}$ & $\begin{array}{l}.076 \\
0.33\end{array}$ & $\begin{array}{l}0.20 \\
0.78\end{array}$ & $\begin{array}{l}-1.49 \\
-3.62\end{array}$ & $\begin{array}{l}-1.61 \\
-3.98\end{array}$ & $\begin{array}{l}-1.49 \\
-3.28\end{array}$ & $\begin{array}{l}-1.74 \\
-3.99\end{array}$ \\
\hline SYR7595 & & & $\begin{array}{l}0.55 \\
1.77\end{array}$ & $\begin{array}{l}0.53 \\
1.78\end{array}$ & $\begin{array}{l}1.17 \\
2.86\end{array}$ & $\begin{array}{l}1.28 \\
3.21\end{array}$ \\
\hline INSTTN & & & $\begin{array}{l}0.39 \\
2.80\end{array}$ & $\begin{array}{l}0.43 \\
3.09\end{array}$ & $\begin{array}{c}0.57 \\
3.372\end{array}$ & $\begin{array}{l}0.62 \\
3.62\end{array}$ \\
\hline CAPCON1 & $\begin{array}{l}-1.11 \\
-1.71 *\end{array}$ & & $\begin{array}{l}-0.10 \\
-0.17 \\
\end{array}$ & & $\begin{array}{c}-.94 \\
-1.24\end{array}$ & \\
\hline CAPCON2 & & $\begin{array}{l}-0.79 \\
-1.23 \\
\end{array}$ & & $\begin{array}{l}-0.24 \\
-0.43\end{array}$ & & $\begin{array}{l}-0.94 \\
-1.42 \\
\end{array}$ \\
\hline $\begin{array}{c}\text { Latin } \\
\text { American } \\
\text { Dummy } \\
\end{array}$ & & & $\begin{array}{l}-.094 \\
-1.82\end{array}$ & $\begin{array}{l}-0.81 \\
-1.55\end{array}$ & $\begin{array}{l}-1.52 \\
-2.40\end{array}$ & $\begin{array}{l}-1.26 \\
-2.14\end{array}$ \\
\hline $\begin{array}{c}\text { Sub-Saharan } \\
\text { Africa } \\
\text { Dummy } \\
\end{array}$ & & & $\begin{array}{l}-3.01 \\
-4.99\end{array}$ & $\begin{array}{l}-3.04 \\
-5.03\end{array}$ & $\begin{array}{l}-2.93 \\
-4.50\end{array}$ & $\begin{array}{l}-2.71 \\
-4.21\end{array}$ \\
\hline $\begin{array}{c}\text { East Asian } \\
\text { Dummy }\end{array}$ & & & $\begin{array}{l}1.74 \\
2.76 \\
\end{array}$ & $\begin{array}{r}1.84 \\
-3.10 \\
\end{array}$ & $\begin{array}{c}0.378 \\
0.46 \\
\end{array}$ & $\begin{array}{l}0.79 \\
1.11 \\
\end{array}$ \\
\hline Observations & 116 & 105 & 80 & 81 & 61 & 61 \\
\hline R-Square & 0.04 & 0.04 & 0.56 & 0.56 & 0.64 & 0.65 \\
\hline
\end{tabular}

\footnotetext{
${ }^{23}$ The first number in each cell is the coefficient and the second number is the t-ratio. $*$ : significant at $10 \%, * *$ : significant at $5 \%, * * *$ : significant at $1 \%$.
} 
Table 3

Capital Controls (CAPCON), Ethnic Homogeneity and Economic Growth ${ }^{24}$ (Dependent Variable: Growth Rate per Capita 1976-95)

\begin{tabular}{|c|c|c|c|c|c|c|c|c|}
\hline & $\overline{1}$ & $\overline{2}$ & $\overline{3}$ & $\overline{4}$ & $\overline{5}$ & $\overline{6}$ & $\overline{7}$ & $\overline{8}$ \\
\hline & $\begin{array}{c}\text { All } \\
\text { Countries }\end{array}$ & $\begin{array}{c}\text { All } \\
\text { Countries }\end{array}$ & $\begin{array}{c}\text { All } \\
\text { Countries }\end{array}$ & $\begin{array}{c}\text { All } \\
\text { Countries }\end{array}$ & $\begin{array}{c}\text { Non } \\
\text { OECD }\end{array}$ & $\begin{array}{c}\text { Non } \\
\text { OECD }\end{array}$ & $\begin{array}{l}\text { No HKG } \\
\& \text { TWN }\end{array}$ & $\begin{array}{r}\text { No HKG } \\
\text { \& TWN }\end{array}$ \\
\hline Log of GDP p.c. 1975 & $\begin{array}{l}-1.66 \\
-4.31\end{array}$ & $\begin{array}{l}-1.76 \\
-4.57\end{array}$ & $\begin{array}{l}-1.65 \\
-4.38\end{array}$ & $\begin{array}{l}-1.78 \\
-4.89\end{array}$ & $\begin{array}{l}-1.58 \\
-3.80\end{array}$ & $\begin{array}{l}-1.83 \\
-4.63\end{array}$ & $\begin{array}{l}-1.64 \\
-4.34\end{array}$ & $\begin{array}{l}-1.77 \\
-4.80\end{array}$ \\
\hline SYR7595 & $\begin{array}{c}0.41 \\
1.438\end{array}$ & $\begin{array}{l}0.50 \\
1.77\end{array}$ & $\begin{array}{l}.48 \\
1.68\end{array}$ & $\begin{array}{l}0.49 \\
1.84\end{array}$ & $\begin{array}{l}1.08 \\
2.77\end{array}$ & $\begin{array}{l}1.15 \\
3.18\end{array}$ & $\begin{array}{l}0.43 \\
1.80\end{array}$ & $\begin{array}{l}0.45 \\
1.63\end{array}$ \\
\hline CAPCON1 & $\begin{array}{l}-0.70 \\
-1.25\end{array}$ & & $\begin{array}{c}-3.77 \\
-2.33^{* *}\end{array}$ & & $\begin{array}{l}-4.78 \\
-2.56 * *\end{array}$ & & $\begin{array}{c}-3.91 \\
-2.41 * *\end{array}$ & \\
\hline CAPCON1*ELH & & & $\begin{array}{c}4.45 \\
2.02 * *\end{array}$ & & $\begin{array}{l}5.24 \\
1.88^{*}\end{array}$ & & $\begin{array}{c}4.76 \\
2.13 * *\end{array}$ & \\
\hline CAPCON2 & & $\begin{array}{l}-0.48 \\
-0.89\end{array}$ & & $\begin{array}{c}-4.92 \\
-3.16^{* * *}\end{array}$ & & $\begin{array}{c}-5.88 \\
-3.4 * * *\end{array}$ & & $\begin{array}{c}-4.94 \\
-3.17 * * *\end{array}$ \\
\hline CAPCON2*ELH & & & & $\begin{array}{c}5.96 \\
3.02 * * *\end{array}$ & & $\begin{array}{c}6.57 \\
3.00^{* * *}\end{array}$ & & $\begin{array}{c}6.06 \\
3.06^{* * *}\end{array}$ \\
\hline$E L H$ & $\begin{array}{c}3.39 \\
3.60^{* * *}\end{array}$ & $\begin{array}{c}2.85 \\
3.13^{* * *}\end{array}$ & $\begin{array}{l}-0.34 \\
-0.16\end{array}$ & $\begin{array}{l}-1.01 \\
-0.65\end{array}$ & $\begin{array}{c}-1.50 \\
0.56\end{array}$ & $\begin{array}{l}-2.35 \\
-1.31\end{array}$ & $\begin{array}{l}-0.72 \\
-0.34\end{array}$ & $\begin{array}{l}-1.18 \\
-0.76\end{array}$ \\
\hline INSTTN & $\begin{array}{l}0.36 \\
2.73\end{array}$ & $\begin{array}{l}0.41 \\
3.06\end{array}$ & $\begin{array}{l}0.38 \\
2.99\end{array}$ & $\begin{array}{l}0.44 \\
3.48\end{array}$ & $\begin{array}{l}0.58 \\
3.72\end{array}$ & $\begin{array}{l}0.63 \\
4.06\end{array}$ & $\begin{array}{l}0.39 \\
3.04\end{array}$ & $\begin{array}{l}0.45 \\
3.52\end{array}$ \\
\hline $\begin{array}{c}\text { Latin American } \\
\text { Dummy }\end{array}$ & $\begin{array}{l}-1.23 \\
-2.53\end{array}$ & $\begin{array}{l}-1.00 \\
-2.02\end{array}$ & $\begin{array}{l}-1.20 \\
-2.51\end{array}$ & $\begin{array}{l}-0.99 \\
-2.10\end{array}$ & $\begin{array}{l}-1.72 \\
-3.03\end{array}$ & $\begin{array}{l}-1.36 \\
-2.54\end{array}$ & $\begin{array}{l}-1.21 \\
-2.53\end{array}$ & $\begin{array}{l}-0.99 \\
-2.11\end{array}$ \\
\hline $\begin{array}{c}\text { Sub-Saharan Africa } \\
\text { Dummy }\end{array}$ & $\begin{array}{l}-1.25 \\
-2.15 \\
\end{array}$ & $\begin{array}{l}-1.61 \\
-2.20 \\
\end{array}$ & $\begin{array}{l}-1.08 \\
1.52 \\
\end{array}$ & $\begin{array}{l}-0.71 \\
-0.93 \\
\end{array}$ & $\begin{array}{l}-1.21 \\
-1.611 \\
\end{array}$ & $\begin{array}{l}-0.83 \\
1.06 \\
\end{array}$ & $\begin{array}{l}-1.18 \\
-1.64 \\
\end{array}$ & $\begin{array}{l}-0.82 \\
-1.06 \\
\end{array}$ \\
\hline $\begin{array}{c}\text { East Asia } \\
\text { Dummy }\end{array}$ & $\begin{array}{l}2.40 \\
3.93 \\
\end{array}$ & $\begin{array}{l}2.55 \\
4.21 \\
\end{array}$ & $\begin{array}{l}2.16 \\
3.54 \\
\end{array}$ & $\begin{array}{l}2.30 \\
3.97 \\
\end{array}$ & $\begin{array}{l}0.75 \\
0.97 \\
\end{array}$ & $\begin{array}{l}1.04 \\
1.45 \\
\end{array}$ & $\begin{array}{l}1.95 \\
2.98 \\
\end{array}$ & $\begin{array}{l}2.11 \\
3.38 \\
\end{array}$ \\
\hline Obsvns. & 82 & 82 & 82 & 82 & 62 & 62 & 80 & 80 \\
\hline$R$-Square & 0.63 & 0.62 & 0.65 & 0.66 & 0.71 & 0.72 & 0.63 & 0.64 \\
\hline
\end{tabular}

${ }^{24}$ ELH refers to Ethno Linguistic Homogeneity. 


\section{Table 4}

Robustness Results for CAPCON1, CAPCON2 and Ethno-Linguistic Homogeneity

(Dependent Variable: Growth Rate of GDP per cap 1975-95)

(Hong Kong, Korea, Singapore and Taiwan Excluded from Sample)

\begin{tabular}{|l|l|l|l|l|l|l|}
\hline & 1 & 2 & 3 & 4 & 5 (No OECD) & 6 (No OECD) \\
\hline CAPCON1 & -4.70 & & -5.13 & & -6.10 & \\
& $-2.98^{* * *}$ & & $-3.70^{* * *}$ & & $-3.54^{* * *}$ & \\
\hline CAPCON1 ${ }^{*}$ ELH & 5.65 & & 6.53 & & 7.64 & \\
& $2.58^{* *}$ & & $3.17^{* * *}$ & & $2.74^{* * *}$ & \\
\hline CAPCON2 & & -5.12 & & -5.04 & & -6.14 \\
& & $-3.31^{* * *}$ & & $-3.59^{* * *}$ & & $-3.71^{* * *}$ \\
\hline CAPCON2*ELH & & 6.12 & & 6.23 & & 7.25 \\
& & $3.12^{* * *}$ & & $3.41^{* * *}$ & & $3.44^{* * *}$ \\
\hline ELH & -2.65 & -1.81 & -0.56 & -1.73 & -5.54 & -4.72 \\
& -1.34 & -1.13 & -0.08 & -0.24 & -0.69 & -0.58 \\
\hline $\begin{array}{l}\text { Investment } \\
\text { Ratio (1975-95) }\end{array}$ & & & 1.34 & 1.15 & 0.80 & 1.20 \\
\hline $\begin{array}{l}\text { Inflation Rate } \\
\text { (1975-95) }\end{array}$ & & & -0.002 & -0.001 & -0.002 & -0.001 \\
\hline Life Expectancy & & $-4.26^{* * *}$ & $-3.97^{* * *}$ & $-3.89^{* * *}$ & $-3.12^{* * *}$ \\
(1975) & & 0.11 & 0.09 & 0.08 & 0.03 \\
\hline $\begin{array}{l}\text { Trade Volume } \\
\text { (1975-95) }\end{array}$ & & & $2.96^{* * *}$ & $2.26^{* *}$ & $1.71^{*}$ & 0.47 \\
\hline ELH* LGDPC75 & & -0.01 & -0.02 & -0.02 & -0.02 \\
& & & $-3.55^{* * *}$ & $-3.36^{* * *}$ & $-2.96^{* * *}$ & $-2.93^{* * *}$ \\
\hline ELH* INSTTN & & -0.55 & -0.06 & -0.06 & 0.49 \\
& & & -0.55 & -0.06 & -0.05 & 0.41 \\
\hline Observations & 78 & 78 & 6.08 & -0.13 & 0.31 & -0.38 \\
\hline R-Square & 0.56 & 0.58 & 0.77 & 0.73 & 0.82 & 0.79 \\
\hline
\end{tabular}

In each of the above regressions, the following variables were also included: Log of GDP per capita 1975, Average Years of Secondary Schooling (SYR7595), Institutional Quality (ICRGE Index), Latin America Dummy, Sub-Saharan Africa Dummy and East Asia Dummy. 
Table 5

More Robustness Results

(Dependent Variable: Growth Rate of GDP per cap 1975-95)

\begin{tabular}{|c|c|c|c|c|c|c|}
\hline & (1) & (2) & (3) & (4) & (5) & (6) \\
\hline $\begin{array}{l}\log \text { of GDP p.c. } \\
1975\end{array}$ & $\begin{array}{c}-2.293 \\
-5.88 * * * \\
\end{array}$ & $\begin{array}{c}-2.367 \\
-6.03 * * *\end{array}$ & $\begin{array}{c}-1.703 \\
-4.10 * * *\end{array}$ & $\begin{array}{c}-1.582 \\
-3.87 * * *\end{array}$ & $\begin{array}{c}-2.28 \\
-5.72 * * * \\
\end{array}$ & $\begin{array}{c}-2.39 \\
-6.14 * * *\end{array}$ \\
\hline SYR7595 & $\begin{array}{c}0.798 \\
2.49 * *\end{array}$ & $\begin{array}{c}0.781 \\
2.53 * *\end{array}$ & $\begin{array}{c}0.981 \\
2.91 * * *\end{array}$ & $\begin{array}{c}0.89 \\
2.70 * * *\end{array}$ & $\begin{array}{c}0.388 \\
0.81 \\
\end{array}$ & $\begin{array}{c}0.511 \\
1.39 \\
\end{array}$ \\
\hline CAPCON1 & $\begin{array}{c}-6.107 \\
-3.56 * * *\end{array}$ & & & & $\begin{array}{c}-7.722 \\
-4.60 * * *\end{array}$ & \\
\hline$C A P C O N 1 * E L H$ & $\begin{array}{c}7.592 \\
3.20 * * *\end{array}$ & & & & $\begin{array}{c}7.225 \\
2.77 * * *\end{array}$ & \\
\hline CAPCON2 & & $\begin{array}{c}-6.943 \\
-3.92 * * *\end{array}$ & & & & $\begin{array}{c}-8.439 \\
-5.42 * * * \\
\end{array}$ \\
\hline$C A P C O N 2 * E L H$ & & $\begin{array}{c}8.795 \\
3.87 * * *\end{array}$ & & & & $\begin{array}{c}9.002 \\
4.36 * * * \\
\end{array}$ \\
\hline$E L H$ & $\begin{array}{c}4.858 \\
1.00\end{array}$ & $\begin{array}{c}0.8088 \\
0.15\end{array}$ & $\begin{array}{l}1.448 \\
0.96\end{array}$ & $\begin{array}{l}1.813 \\
1.23\end{array}$ & $\begin{array}{l}-2.85 \\
-1.17\end{array}$ & $\begin{array}{c}-3.97 \\
-2.36 * *\end{array}$ \\
\hline INSTTN & $\begin{array}{c}0.657 \\
5.28 * * *\end{array}$ & $\begin{array}{c}0.667 \\
5.32 * * *\end{array}$ & $\begin{array}{c}0.203 \\
1.17\end{array}$ & $\begin{array}{l}0.16 \\
0.94\end{array}$ & $\begin{array}{c}0.624 \\
5.00 * * *\end{array}$ & $\begin{array}{c}0.691 \\
5.49 * * *\end{array}$ \\
\hline$E L H-S Q$ & $\begin{array}{l}-6.591 \\
-2.08 * *\end{array}$ & $\begin{array}{l}-3.419 \\
-0.99 \\
\end{array}$ & & $\begin{array}{c}1.813 \\
1.23 \\
\end{array}$ & & \\
\hline$L B M P^{*} E L H$ & & & $\begin{array}{l}0.744 \\
1.72 * \\
\end{array}$ & $\begin{array}{c}0.605 \\
1.43 \\
\end{array}$ & & \\
\hline$L B M P$ & & & $\begin{array}{c}-0.921 \\
-2.89 * * * \\
\end{array}$ & $\begin{array}{c}-0.791 \\
-2.52 * *\end{array}$ & & \\
\hline $\begin{array}{c}\text { CAPCON1* } \\
\text { SYR7595 }\end{array}$ & & & & & $\begin{array}{c}0.776 \\
1.37 \\
\end{array}$ & \\
\hline $\begin{array}{l}\text { CAPCON2* } \\
\text { SYR7595 }\end{array}$ & & & & & & $\begin{array}{c}0.825 \\
1.50 \\
\end{array}$ \\
\hline $\begin{array}{l}\text { Inflation Rate } \\
(1975-95)\end{array}$ & & & $\begin{array}{c}-0.001 \\
-2.23 * *\end{array}$ & $\begin{array}{c}-0.001 \\
-2.32 * *\end{array}$ & & \\
\hline $\begin{array}{l}\text { Trade Volume } \\
\text { (1975-95) }\end{array}$ & & & & $\begin{array}{c}0.006 \\
1.83 * *\end{array}$ & & \\
\hline Observations & 82 & 82 & 75 & 74 & 82 & 82 \\
\hline$R$-Square & 0.54 & 0.54 & 0.54 & 0.55 & 0.53 & 0.55 \\
\hline
\end{tabular}




\section{Table 6}

Political Fragmentation

(Dependent Variable: Growth Rate of GDP per cap 1975-95)

\begin{tabular}{|c|c|c|c|c|}
\hline & (1) & (2) & (3) & (4) \\
\hline $\begin{array}{c}\text { Log of GDP p.c. } \\
1975\end{array}$ & $\begin{array}{c}-1.233 \\
(-2.30)^{* *}\end{array}$ & $\begin{array}{c}-1.372 \\
(-2.60)^{* *} \\
\end{array}$ & $\begin{array}{c}-1.193 \\
(-2.20)^{* *}\end{array}$ & $\begin{array}{c}-1.280 \\
(-2.30)^{* *}\end{array}$ \\
\hline CAPCON1 & $\begin{array}{l}1.038 \\
(1.40)\end{array}$ & & $\begin{array}{c}1.173 \\
(1.89)^{*}\end{array}$ & \\
\hline CAPCON1 *LDM & $\begin{array}{c}-0.133 \\
(-2.21)^{* *} \\
\end{array}$ & & & \\
\hline CAPCON2 & & $\begin{array}{l}1.614 \\
(1.85)^{*}\end{array}$ & & $\begin{array}{c}1.773 \\
(2.11)^{* *}\end{array}$ \\
\hline CAPCON2*LDM & & $\begin{array}{c}-0.164 \\
(-2.47)^{* *}\end{array}$ & & \\
\hline CAPCON1*EFEC & & & $\begin{array}{l}-0.062 \\
(-1.56)\end{array}$ & \\
\hline CAPCON2*EFEC & & & & $\begin{array}{c}-0.125 \\
(-2.14)^{* *}\end{array}$ \\
\hline$L D M$ & $\begin{array}{c}0.127 \\
(2.03)^{*}\end{array}$ & $\begin{array}{c}0.127 \\
(1.90)^{*}\end{array}$ & & \\
\hline EFEC & & & $\begin{array}{c}0.097 \\
(2.02)^{*}\end{array}$ & $\begin{array}{l}0.111 \\
(2.02)^{*}\end{array}$ \\
\hline INSTTN & $\begin{array}{c}0.752 \\
(3.95)^{* * * *} \\
\end{array}$ & $\begin{array}{c}0.795 \\
(3.78)^{* * *} \\
\end{array}$ & & $\begin{array}{c}0.841 \\
(3.82)^{* * *} \\
\end{array}$ \\
\hline $\begin{array}{c}\text { Inflation Rate } \\
(1975-95)\end{array}$ & & & & \\
\hline Observations & 36 & 35 & 37 & 35 \\
\hline$R$-Square & 0.52 & 0.53 & 0.53 & 0.55 \\
\hline
\end{tabular}

LDM refers to the log of district magnitude adjusted for institutional quality and EFEC refers to the effective number of parties adjusted for institutional quality. See text and Stein, Talvi and Grisanti (1999) for further details. 